\title{
Protection of the Environment through the Lens of Syria: Scrutinizing the Loopholes in the Prevailing Legislative Framework
}

\author{
Alexandra Prus* \\ https://doi.org/10.21827/GroJIL.8.1.48-68
}

\begin{abstract}
Keywords
INTERNATIONAL HUMANITARIAN ENVIRONMENT; ARMED CONFLICTS
\end{abstract}

LAW; PROTECTION OF

THE

\begin{abstract}
This paper critically analyzes selected aspects of the current legal framework regarding the protection of the environment during the non-international armed conflict in Syria. The water damage that is occurring in Syria is particularly scrutinized. Preserving the environment is essential for safeguarding the planet for future generations. The potentiality of any armed conflict not only poses a threat to the peace and safety of the environment but can have exhaustive repercussions. Therefore, this topic is of the utmost importance and the objective of my research is to examine the relevant law, or the lack thereof. International humanitarian law will be placed at the forefront, along with customary international law which will provide an alternative approach. Where necessary, secondary sources will supplement the research in order to broaden its scope. The meaning of the 'natural environment' as opposed to the 'environment' will be assessed and applied to the water damage in order to establish whether or not it can be considered damage to the natural environment. A comparative approach will be taken for the purpose of analyzing all pertinent sources, with the intention of providing a conclusion that showcases the environment as the silent victim of armed conflicts.
\end{abstract}

\section{Introduction}

The advance of technology over the years has empowered weapons to be more destructive than ever, making the environment a silent victim of armed conflicts worldwide. ${ }^{1}$ Armed conflict can have bounteous and unforgiving repercussions for the environment, resulting in the eradication of infrastructure, pollution of the water supply, contamination of terrain and soil, demolition of crops and forests, and over-exploitation of natural resources. ${ }^{2}$ Although, in terms of warfare, the environment is acknowledged, it has never been a top priority, despite being invariably present during military operations. ${ }^{3}$ Therefore, although protection is

Current LLB student of International and European Law at the University of Groningen. The author would like to thank Ms Marlies Hesselman LLM for her comments and feedback. All errors are her own.

1 United Nations Environment Programme, 'Rooting for the environment in times of conflict and war' (United Nations Environment Programme, 6 November 2019) <unenvironment.org/news-and-stories/story/rootingenvironment-times-conflict-and-war> accessed 9 July 2020.

2 Rafael Huseynov, 'Armed conflicts and the environment' (Doc. 12774, Committee on the Environment, Agriculture and Local and Regional Affairs, Parliamentary Assembly of the Council of Europe, 17 October 2011) <reliefweb.int/sites/reliefweb.int/files/resources/Full_Report_2660.pdf> accessed 9 July 2020.

3 Gareth Edwards-Jones, 'Agricultural Policy and Environment in Syria: The Cases of Rangeland Grazing and Soil Management' in Ciro Fiorillo and Jacques Vercueil (eds), FAO Agricultural Policy and Economic Development Series No 8: Syrian agriculture at crossroads (FAO 2003). 


\section{Protection of the Environment through the Lens of Syria: Scrutinizing the Loopholes in the Prevailing Legislative Framework 49}

provided by several legal instruments to a certain extent, the potential of an armed conflict poses a threat to the safety of the environment. Moreover, it is not solely the environment that is ubiquitous, but also environmental considerations within the international legal sphere. ${ }^{4}$

Nowadays, various internal conflicts are being fought which are resulting in environmental damage. Unfortunately, Syria's fragile environment has become a victim due to the relentless internal conflict. ${ }^{5}$ The conflict commenced in 2011, as what at first appeared to be scattered protests suddenly turned into an uprising, questioning the position of President Assad. ${ }^{6}$ The internal conflict erupted essentially between two main actors: President Assad, with support of the national Syrian Arab Army (SAA), and non-governmental armed groups. ${ }^{7}$ Notice will be made of the difference between non-international armed conflict (NIAC) and international armed conflict (IAC), and focus will be placed on the internal conflict evolving in Syria as opposed to the international conflicts that are also present. ${ }^{8}$ The unfolding of the attacks has caused significant damage to the already fragile state of the environment. ${ }^{9}$ There are multiple environmental areas that are experiencing noticeable damage as a result of the attacks, such as infrastructure. However, focus will be placed on the water system and how the effects of its destruction continue to pose a threat to the health and safety of the environment and the well-being of citizens. ${ }^{10}$

4 ILC, 'Protection of the environment in relation to armed conflicts' (28 May 2013) UN Doc A/70/10.

5 Wim Zwijnenburg, 'The Human Cost of War's Environmental Impact' (Syria Untold, 11 October 2016) <syriauntold.com/2016/10/11/the-human-cost-of-wars-environmental-impact/> accessed 9 July 2020.

6 Wim Zwijnenburg and Kristine te Pas, Amidst the debris... A desktop study on the environmental and public health of Syria's conflict (Pax 2015) 11.

7 Amichai Cohen, 'Syria - International Use of Force and Humanitarian Intervention' (2019) <papers.ssrn.com/sol3/papers.cfm?abstract_id=3380220> accessed 5 April 2020, 11; see further Tom Gal, 'Legal Classification of the Conflict(s) in Syria' in Hilly Khen, Nir Boms, and Sareta Ashraph (eds), The Syrian War: Between Justice and Political Reality (Cambridge University Press 2019), 43 - Gal states: 'besides the conflict between President Assad and non-governmental armed groups, even smaller internal conflicts are taking place such as between various armed groups'. Note, a conflict between one or more non-State armed groups can also fall under the scope of non-international armed conflict. However, this will not be the primary focal point.

8 Bart De Schutter and Christine Van De Wyngaert, 'Coping with Non-International Armed Conflicts: The Borderline between National and International Law' (1983) 13 Georgia Journal of International and Comparative Law 279; Jelena Pejic, 'The protective scope of Common Article 3: more than meets the eye' (2011) 93 International Review of the Red Cross 189; ICRC, 'Non-international armed conflict' (International Committee of the Red Cross, 2020) <casebook.icrc.org/law/non-international-armed-conflict> accessed 9 July 2020; Non-international armed conflict will be the primary focus, as opposed to international armed conflicts, because after the Second World War there has been a shift towards predominantly internal conflicts. Hence, over the years, there have been various internal conflicts emerging as opposed to international armed conflict. This is not to exclude the fact that in Syria both types of conflict are taking place. This will be further explained and acknowledged in the relevant sections of this thesis; see Gal (n 7) 34-43 for further explanation of the involvement of States such as the United States, Iran and Turkey resulting in international conflicts within Syria.

9 Zwijnenburg and te Pas ( $\mathrm{n}$ 6); see The World Bank, 'The Toll of War: The Economic and Social Consequences of the Conflict in Syria (The World Bank Group, 10 July 2017) $<$ worldbank.org/en/country/syria/publication/the-toll-of-war-the-economic-and-social-consequences-ofthe-conflict-in-syria $>$ accessed 9 July 2020.

10 Zwijnenburg and te Pas (n 6) 7, 11, 18, 19; it must be acknowledged that there are several other forms of damage to the environment occurring as a result of the conflict, namely: direct and indirect damage in relation to oil refineries; damage to industrial sites; damage to the electricity network and the weakening of the waste 
The main aim of this thesis is to investigate this legal problem: does the international legal framework effectively protect the environment, more specifically the water system, in the case of the Syrian armed conflict? It must be remembered that in international humanitarian law (IHL) there are three stages: jus ad bellum, jus in bello and jus post bellum. The focal point of this thesis will be the specific jus in bello that is applicable to non-international armed conflict, with the case study of Syria. ${ }^{11}$ Thus, the analysis will firstly introduce the Syrian conflict and provide some background information as to the nature of the environmental damage. The Geneva Conventions of 1949, specifically Common Article 3, Articles 35(3) and 55(1) of Additional Protocol I (API), and Articles 14 and 15 of Additional Protocol II (APII), will be examined. ${ }^{12}$ These provisions will be applied to the Syrian conflict in the last section to assess whether IHL may offer protection to the environment and terminate the damage caused to the water system by the armed attacks.

To further enhance the research into the question of the damage occurring, it is crucial to explain the meaning of 'natural environment' and consider whether the harm caused to the water system qualifies as damage to the natural environment. The natural environment is not clearly defined in legislation. It is generally protected through IHL as opposed to international environmental law, because the jus in bello covers the law of armed conflict. Hence, it is considered that environmental damage is a humanitarian issue. ${ }^{13}$

A variety of propositions of definitions will be examined, from the International Court of Justice (ICJ), the International Law Commission (ILC), and the Stockholm Declaration. ${ }^{14}$ The next problems assessed will be what the natural environment consists of and whether it is different from simply the 'environment'. This analysis of the definition of 'natural environment' will aim to show that the legislative framework does not sufficiently address the importance and scope of the natural environment. ${ }^{15}$

management system. Weapons-related contamination caused by both the government and armed groups has also resulted in damage such as toxic remnants, explosive substances and the making of unsafe weapons. The reason water-related damage, as opposed to the forms listed above, will be analyzed is its multipurpose and complex nature. The analysis will aim to display how serious a non-international armed conflict can be and to what extent resources can be exploited for the benefit of a given party.

11 Zeyad Mohammad Jaffal and Waleed Fouad Mahameed, Prevent Environmental Damage During Armed Conflict (2018) 5 BRICS Law Journal 72, 74.

12 Geneva Convention Relative to the Protection of Civilian Persons in Time of War (adopted 12 August 1949, entered into force 21 October 1950) 75 UNTS 287, common art 3; Protocol Additional to the Geneva Conventions of 12 August 1949 and Relating to the Protection of Victims of International Armed Conflicts (adopted 8 June 1977, entered into force 7 December 1978) 1125 UNTS 3 (Protocol I) arts 35(3), 55(1); Protocol Additional to the Geneva Conventions of 12 August 1949 and Relating to Protection of the Victims of Non-International Armed Conflicts (adopted 8 June 1977, entered into force 7 December 1978) 1125 UNTS 609 (Protocol II) arts 14, 15 - note, Articles 35(3) and 55(1) apply to international armed conflicts and will be examined as pertinent customary international law.

13 Carl Bruch, Protecting the Environment During Armed Conflict: An Inventory and Analysis of International Law (United Nations Environment Programme 2009) 10; see ILC (n 4) and note Principle 1 which concludes that 'the natural environment shall be protected by applicable international law and in particular, international humanitarian law'.

14 Doug Weir, 'We need to define "the environment" to protect it from armed conflict' (The Toxic Remnants of War Project, 11 February 2016) <toxicremnantsofwar.info/we-need-to-define-the-environment-to-protect-itfrom-armed-conflict/\#_ednref1> accessed 9 July 2020.

15 Carsten Stahn, Jens Iverson, Jennifer S Easterday (eds), Environmental Protection and Transitions from Conflict to Peace: Clarifying Norms, Principles, and Practices (Oxford Scholarship Online 2017). 


\section{Protection of the Environment through the Lens of Syria: Scrutinizing the Loopholes in the Prevailing Legislative Framework 51}

Overall, the purpose is to explore the critical elements of the legal framework that are applicable in times of a non-international armed conflict, specifically the internal conflict in Syria, to come to an analytical conclusion with the idea that, on one hand, the complexity surrounding the protection of the environment is due to a lack of precise legislation, and on the other hand the lack of explicit implementation on the part of States. ${ }^{16}$

\section{Preface to the Case Study: Syria Antecedent to the Internal Battle}

Currently, all over the world, numerous internal conflicts are taking place. Syria is just one of them. The aim of this Section is to present the situation as it was in Syria before the conflict erupted, with special attention placed on the environment.

The Syrian conflict began in 2011 as a series of protests known as 'the Arab Spring', which in Syria originally began in opposition to President Assad's regime. ${ }^{17}$ In May 2012, Human Rights Watch concluded that, in some areas of Syria, the fighting had achieved the level of an armed conflict. ${ }^{18}$ President Assad announced on 26 June 2012 that Syria was indeed in a state of war. ${ }^{19}$ Furthermore, the International Committee of the Red Cross (ICRC) officially confirmed in July 2012 that the situation in Syria had reached the status of a noninternational armed conflict. ${ }^{20}$ It is important to note that there have been a range of disputes taking place in Syria. These include, among others, international armed conflicts involving the United States, Turkey, Israel and Iran. ${ }^{21}$ However, in this thesis, attention will be placed

16 Michelle Mack, Increasing Respect for International Humanitarian Law in Non-international Armed Conflicts' (International Committee of the Red Cross, 2008) $<$ icrc.org/sites/default/files/topic/file_plus_list/0923increasing_respect_for_international_humanitarian_law_in_non-international_armed_conflicts.pdf $>$ accessed 9 July 2020; see Richard Desgagné, The Prevention of Environmental Damage in Time of Armed Conflict: Proportionality and Precautionary Measures' (2000) 3 Yearbook of International Humanitarian Law 109.

17 Council on Foreign Relations, 'Global Conflict Tracker' (Council on Foreign Relations, 11 August 2020) $<$ cfr.org/interactive/global-conflict-tracker/conflict/civil-war-syria> accessed 11 August 2020.

18 Ole Solvang and Anna Neistat, Death from the Skies: Deliberate and Indiscriminate Air Strikes on Civilians (Human Rights Watch 2013) 12

19 Louise Arimatsu and Mohbuba Choudhury, 'The Legal Classification of the Armed Conflicts in Syria, Yemen and Libya' (International Law PP 2014/01, Chatman House 2014) $<$ chathamhouse.org/sites/default/files/home/chatham/public_html/sites/default/files/20140300Classific ationConflictsArimatsuChoudhury1.pdf $>$ accessed 9 July 2020; the type of conflict was not specified by the President but it can be implied that he meant civil war.

20 ibid.

21 See Gal (n 7) 34; see also David Wallace, Amy McCarthy and Shane Reeves, 'Trying the Make Sense of the Senseless: Classifying the Syrian War under the Law of Armed Conflict' (2017) 25 Michigan State International Law Review 556, 589, 591 - firstly, it must be noted that the Syrian conflict is extremely complicated and involves various actors. Note that the authors specifically state ' $(\ldots)$ it is clear that a noninternational armed conflict currently exists in Syria'. They further go on to acknowledge that 'The ICRC agrees, confirming that the situation in Syria with respect to the U.S. constitutes an international armed conflict'. This presents the argument that both types of attack are taking place in Syria. See Stephanie Nebehay, 'Exclusive: Situation in Syria constitutes international armed conflict - Red Cross' (Reuters, 7 April 2017) <reuters.com/article/us-mideast-crisis-syria-redcross-idUSKBN17924T> accessed 9 July 2020; an Israeli air strike occurred on Syrian territory in Damascus in January 2013 and caused controversy as to whether or not this could qualify as a separate international armed conflict. This accentuates the argument that the conflict in Syria is indeed complicated. See Arimatsu and Choudhury (n 19). 
on examining whether the Geneva Conventions, as the appropriate jus in bello, can be applied to the non-international armed conflicts involving the Syrian government and rebel groups. ${ }^{22}$

The internal fighting in Syria is between, on the one hand, President Assad and the Syrian Army, and on the other, non-governmental armed groups supported by external nonState actors such as FSA and ISIS. ${ }^{23}$ The lack of a coherent Syrian army and the rise of armed opposition groups organizing anti-regime protests fueled the development of the civil war and led to the national Syrian Arab Army (SAA) resorting to the use of explosive weapons and cluster munitions in populated areas. ${ }^{24}$ As a result, the citizens and natural environment experienced horrendous destruction of, among other things, infrastructure and the water system. This quickly resulted in a humanitarian crisis with seemingly no end. ${ }^{25}$ This unfortunate battle left countless civilians scarred and having to evacuate their hometowns due to the devastation to the infrastructure. Furthermore, the environment was at a greater risk than ever, as the Syrian government and armed opposition groups showed no mercy. ${ }^{26}$

Attention will be placed solely on non-international armed conflicts involving the Syrian government against the rebel groups and how their conduct and the continuation of the conflict has contributed to the detriment and fragile state of the environment. The damage caused to the water system as a result of the attacks will be analyzed, specifically harm caused to the effective supply of safe water. ${ }^{27}$ The water system is an important aspect of every healthy, functioning society and environment. Hence, failure to protect it can lead to undesirable human suffering. ${ }^{28}$ Focus on this aspect will show that the environmental circumstances in Syria are broad and complex.

It is helpful to recap the environmental situation and issues in pre-conflict Syria to better understand the extent of the harm the internal conflict may cause. A few reports regarding the pre-conflict situation have been released. In 2009, the Delegation of the European Commission to Syria released a report on the Country Environmental Profile of the Syrian Arab Republic, which includes comments and assessments on various matters concerning the state of the environment shortly before the war. ${ }^{29}$ What is evident from the report is that, prior to the start of the internal armed conflict, Syria experienced numerous

22 Gal (n 7) 43.

23 See Cohen (n 7) 11; the challenging aspect is assessing whether or not these armed groups satisfy the organizational criteria laid out by the International Criminal Tribunal for the Former Yugoslavia in the Tadic case. This organizational aspect is vital as it excludes acts which are not organized and therefore do not fall within the framework of international humanitarian law. It is without doubt that the government forces meet this criterion. It can be argued that both FSA and ISIS also do, as they control large amounts of territory, have an organized command structure and are able to carry out organized attacks - see Wallace, McCarthy and Reeves (n 21) 587, 588; see also Arimatsu and Choudhury (n 19).

24 Zwijnenburg and te Pas (n 6) 11.

25 Zwijnenburg and te Pas (n 6) 11.

26 Josef Kraus, 'The Internalization of Conflicts: Theoretical Background, Conceptualization, and Contemporary Middle-East Region' (2017) 26(5) Vojenské rozhledy 23, 29.

27 Zwijnenburg and te Pas (n 6).

28 Peter Gleick, 'Water as a Weapon and Casualty of Conflict: Freshwater and International Humanitarian Law' (2019) 33 Water Resources Management 1737, 1738, 1742, 1743; an example of human suffering as a result of the failure to protect water systems occurred in 1991 during a civil war in Somalia. The destruction of the water system led to a cholera outbreak which in turn affected around 55,000 civilians. An interesting observation by Gleick in this text is that the shift from multi-State conflicts to intra-State civil conflicts has also resulted in an increase in attacks on water systems.

29 Max Kasparek and Marwan Dimashki, 'Country Environmental Profile for the Syrian Arab Republic' (No 2008/171432, Delegation of the European Commission to Syria, April 2009). 


\section{Protection of the Environment through the Lens of Syria: Scrutinizing the Loopholes in the Prevailing Legislative Framework 53}

environmental problems, ${ }^{30}$ namely water pollution, water scarcity, air pollution, waste management issues, mining industry pollution, and environmental policy and governance issues. ${ }^{31}$ As of 2009, when the Report was released, it was claimed that almost all of Syria's renewable water resources were fully exploited. ${ }^{32}$ Hence, water transfer to more rural areas was conducted, but with difficulty. The Report notes that some effects of water shortage are visible, for example the declining aquifer water levels resulting in an increase in the salinity of groundwater. ${ }^{33}$ A shortage of drinking water and drought were very probable, and even experienced in cities near Damascus and Yarmouk, close to the Jordan border. ${ }^{34}$

An interesting argument examined by scholars is the thought that the Syrian drought between 2007-2010 was a possible contribution to the escalation of the internal conflict. Femia and Werrel both state that it was the 'worst long-term drought ... since agricultural civilizations began in the Fertile Cresent'. ${ }^{35}$ Evidence further claims that it was one of the worst recorded droughts in Syria, which resulted in widespread crop failure and migration to urban cities. ${ }^{36}$ This argument was supported by former President of the United States, Barack Obama, who claimed that the drought 'helped fuel the early unrest in Syria, which descended into civil war' ${ }^{37}$ It can be argued that the drought, to a certain extent, might have provoked migration, which also contributed to the internal unrest and resulted in conflict. ${ }^{38}$ However, it would be unconvincing to argue that the drought, and the state of the environment as a result thereof, was the sole cause for the Syrian internal conflict. ${ }^{39}$

A desktop study report released by PAX in 2015 on 'The Environmental and Public Health of the Syrian Conflict' covers the state of the environment prior to the start of the conflict and makes similar claims to the 2009 report by the Delegation of the European Commission to Syria. The PAX report mentions that 'Syria experienced numerous consecutive droughts which affected water and resulted in scarcity with around 1.3 million civilians being affected.' ${ }^{40}$

\footnotetext{
ibid.

31 Zwijnenburg and te Pas (n 6) 18-21; see also Ghaleb Faour and Abbas Fayad, 'Water Environment in the Coastal Basins of Syria - Assessing the Impacts of the War' (2014) Springer International Publishing Switzerland 533-552.

32 Kasparek and Dimashki (n 29) 17.

33 Kasparek and Dimashki (n 29) 18.

34 ibid.

35 Jan Shelby, Omar Dahi, Christiane Fröhlich and Mike Hulme, 'Climate change and the Syrian war revisited' (2017) 60 Political Geography 232, 233; see Francesco Femia and Caitlin Werrell, 'Syria: Climate Change, Drought and Social Unrest' (The Center for Climate and Security, 29 February 2012).

36 Colin Kelley and others, 'Climate change in the Fertile Crescent and implications of the recent Syrian drought' (2015) 112(11) PNAS 3241.

37 Shelby, Dahi, Fröhlich and Hulme (n 35); see Barack Obama, 'Remarks by the President at the United States Coast Guard Academy Commencement' (Office of the Press Secretary, 20 May 2015) $<$ obamawhitehouse.archives.gov/the-press-office/2015/05/20/remarks-president-united-states-coastguard-academy-commencement $>$ accessed 3 April 2020.

38 Shelby, Dahi, Fröhlich and Hulme (n 35).

39 ibid.

40 Zwijnenburg and te Pas (n 6) 19.
} 
Furthermore, the water quality was poor, but this mainly affected areas with a high rate of economic activity. ${ }^{41}$ Another issue brought forward is the failure of an effective wastewater management system. ${ }^{42}$

What must be acknowledged is that Syria's attempt to combat these issues was recognized and addressed in the 10th Five-Year Plan (2006-2010). ${ }^{43}$ The goal set in this Plan was to set up 200 water treatment plants which would extend to around 50 percent of the population. ${ }^{44}$ From this, it can be deduced that the Syrian government was well aware of the environmental problems and set out an initiative to approach and fix them. It can also be noted that Syria had a number of environmental problems regarding the distribution of safe water and the water system prior to the spiraling of the conflict. A few of the effects on the water system during the Syrian internal conflict will be further discussed below.

\section{A. The Syrian Water Conflict: Furtive Environmental Damage in Disguise}

The water crisis in Syria has progressed and worsened along with the conflict, as attacks damaged pipelines and other water infrastructure. Thus, this Section will showcase how, during the internal armed conflict, multiple military attacks have targeted the water system. The water supply system is being damaged as a result of attacks by both the rebel forces and President Assad's regime. ${ }^{45}$ Due to this severe and continuous damage, water is becoming more scarce. ${ }^{46}$ Among other media outlets, this has caught the attention of the International Committee of the Red Cross. They are aware and concerned about the limited access to water, as possible contaminations can have serious repercussions. An insightful claim made by the ICRC was that water, as a scarce resource, should not be used as a weapon of war. This captures the intensity of the conflict and the depth of its impact. ${ }^{47}$

A few examples of attacks on the water system will be presented. However, due to the controversial and highly sensitive nature of the internal conflict, the coverage of the damage being caused by both sides has potential loopholes. The problem first became highlighted in 2014, when the Aleppo and Deir ez-Zor governorates cut off the water supply. ${ }^{48}$ In 2014 , The Syrian Arab News Agency also covered a terrorist attack that took place targeting two water wells in the Sweida area. ${ }^{49}$ Another attack by an armed terrorist group happened at the border of the Daraa province, in which an electrical transformer at a drinking water well was

41 ibid.

42 ibid.

43 United Nations Development Programme, 'Technical Support for the Implementation of the Tenth Five Year Plan' (Project No SYR/08/004, United Nations Development Programme, 5 February 2008) <info.undp.org/docs/pdc/Documents/SYR/00049469_implementing\%20FYP.pdf> accessed 9 July 2020.

44 United Nations Development Programme (n 43); Zwijnenburg and te Pas (n 6) 19.

45 Zwijnenburg and te Pas (n 6) 29.

46 UNICEF, 'Severe water shortages compound the misery of millions in war-torn Syria - says UNICEF' (UNICEF, 25 August 2015) < unicef.org/media/media_82980.html> accessed 9 July 2020.

47 ICRC, 'Environment and international humanitarian law' (International Committee of the Red Cross, 29 October 2010) <icrc.org/en/doc/war-and-law/conduct-hostilities/environment-warfare/overview-environmentand-warfare.htm $>$ accessed 9 July 2020.

48 Zwijnenburg and te Pas (n 6) 29; see inter alia, Office for the Coordination of Humanitarian Affairs, 'Syrian Arab Republic: Governorates Profile' (United Nations, 14 July 2014) $<$ reliefweb.int/sites/reliefweb.int/files/resources/Syria\%20governorate\%20profiles\%206\%20August $\% 2020$ 14.pdf $>$ accessed 9 July 2020 explaining the different governorates in Syria. The report also states which governorates have limited access to water.

49 Zwijnenburg and te Pas (n 6) 29; H Zain, 'Terrorists attack drinking water wells in Syria' (SANA, 10 August 2014) <sana.sy/en/?p=9610> accessed 9 July 2020. 


\section{Protection of the Environment through the Lens of Syria: Scrutinizing the Loopholes in the Prevailing Legislative Framework 55}

detonated.$^{50}$ In 2015, UNICEF released a document estimating that 'around 5 million people are suffering as a result of water shortages: around 2.3 million in Aleppo, about 2.5 million in Damascus, with the remainder being in Dera'a. ${ }^{51}$ This is quite alarming, as in 2015 the population of Syria was just under 18 million inhabitants, which would insinuate that a little under $30 \%$ of the whole population was enduring water shortage. ${ }^{52}$ Furthermore, the World Health Organization has taken notice of the water damage, alerting and reiterating that in 2014 the availability of safe water within Syria was a third of what it was before the conflict. ${ }^{53}$ Damage has also been done to other water infrastructure which ultimately has led to an increased risk of waterborne diseases: cholera, shigella, typhoid, and hepatitis A. ${ }^{54}$ What is more, the provinces of Hama and Homs experienced a loss of water due to attacks on the water infrastructure and thereby also risked the spread of waterborne diseases. ${ }^{55}$ Evidently, the damage is causing serious side effects which affect not only civilians but also the environment.

\section{B. An Introduction to the Jus in Bello: NIAC and IAC}

Jus in bello, alternatively known as the 'law of armed conflict' or international humanitarian law, seeks to control the conduct of parties during an armed conflict. ${ }^{56}$ Firstly, scrutinizing this area of law is indispensable, because it will provide the basis for an analysis of whether or not it is applicable to the Syrian internal conflict. It is important to note that there are multiple provisions available within the international legal framework, and reference will be made to those regarding armed conflicts. Once the applicable provisions have been explained, the next aspect that must be discussed is the differentiation between IAC and NIAC, followed by a commentary on the conflict in Syria. Hence, whether or not there is any distinction between NIAC and IAC will determine whether the provisions could be utilized to protect the environment from further damage.$^{57}$ Firstly, the pertinent law relating to armed conflict will be introduced.

A widely recognized source of law that is relevant to the protection of the environment in the case of non-international armed conflict is the 1949 Geneva Conventions. Within the Conventions, the following provisions will be observed: Common Article 3, Articles 35(3) and 55(1) of Additional Protocol I, and Articles 14 and 15 of Additional Protocol II. ${ }^{58}$ Notably,

50 ibid.

51 UNICEF (n 46); in Aleppo, for example, damage was caused to the sewage system and this caused pollution of the drinking water; see Zwijnenburg and te Pas (n 6) 29.

52 Worldometer, 'Syria Population' (Worldometer) <worldometers.info/world-population/syria-population/> accessed 9 July 2020.

53 Regional Office for the Eastern Mediterranean Syrian Arab Republic, WHO Response to the Conflict in $\begin{array}{llllll}\text { Syria Situation } & \text { Report } \quad \text { \#4 } & \text { (WHO, } & 15\end{array}$ <emro.who.int/images/stories/syria/SituationReport_20140615.pdf> accessed 9 July 2020.

54 ibid.

55 Zwijnenburg and te Pas (n 6) 29.

56 ICRC, 'What are jus ad bellum and jus in bello?' (International Committee of the Red Cross, 22 January 2015) $<$ icrc.org/en/document/what-are-jus-ad-bellum-and-jus-bello-0> accessed 9 July 2020 - note, jus in bello and international humanitarian law mean the same thing and will therefore be used interchangeably throughout this thesis.

57 NIAC stands for 'non-international armed conflict' and IAC stand for 'international armed conflict'. From here, these terms will be used interchangeably in this thesis.

58 Note, although Articles 35(3) and 55(1) of Additional Protocol I are applicable to international armed conflict, they will be assessed as provisions of customary international law that is applicable in non-international armed conflict. 
the Geneva Conventions render only Common Article 3 and Additional Protocol II pertinent to a NIAC, thereby excluding the applicability of Articles 35(3) and 55(1). ${ }^{59}$ Since the focal point of this thesis is on the Syrian internal conflict, the Articles relevant to IAC will not be elaborated on in the same manner as the Articles relating to NIAC. However, they will be examined from the viewpoint of customary international law in addition to the Martens Clause.

\section{Addressing Common Article 3 and Additional Protocol II: An Imperfect Area of Law}

Common Article 3 states that 'In the case of armed conflict not of an international character occurring in the territory of one of the High Contracting Parties, each Party to the conflict shall be bound to apply, as a minimum, the following provisions: $(\ldots)^{\prime 60}$. Moreover, it must be noted that Common Article 3 applies to every conflict that is a confirmed NIAC. Additional Protocol II has a more narrow scope of application, thus not every NIAC is subject thereto. ${ }^{61}$ APII relates to the protection of victims of NIAC, with Articles 14 and 15 relating to the environment. ${ }^{62}$ It is necessary to clearly explain Common Article 3 and Additional Protocol II in order to assess whether they can protect the natural environment and, if so, to what extent they can be applied.

Common Article 3 is rather transparent; it is applicable when a non-international armed conflict takes place within the borders of a High Contracting Party. ${ }^{63}$ It lays out minimum standards of protection for civilians and persons not actively participating in hostilities. ${ }^{64}$ However, it is a general provision and it does not mention or refer to the natural environment, or the environment in any sense..$^{65}$ The general consensus is that since Common Article 3 does not allude to the natural environment in its text, it is not applicable to the protection thereof. However, Jeanique Pretorious offers an optimistic standpoint and explains how a broad interpretation could potentially allow for 'indirect environmental protection'. ${ }^{66}$ He claims that 'Common Article 3 may prohibit environmental damage to the extent that such warfare causes violence to life and person; cruel treatment and torture; outrages on personal dignity; or degrading treatment, which are all expressly prohibited by Common Article 3. ${ }^{67}$

Although this interesting opinion goes against the general view that Common Article 3 does not extend to the protection of the environment, the chances of this argumentation

59 Protocol I (n 12) arts 35(3), 55(1); for reference, Article 35(3) reads: it is prohibited to employ methods or means of warfare which are intended, or may be expected, to cause widespread, long-term and severe damage to the natural environment.' Article 55(1) reads: 'Care shall be taken in warfare to protect the natural environment against widespread, long-term and severe damage. This protection includes a prohibition of the use of methods or means of warfare which are intended or may be expected to cause such damage to the natural environment and thereby to prejudice the health or survival of the population.'; see Gal (n 7) 43, 44. Geneva Convention Relative to the Protection of Civilian Persons in Time of War (n 12) common art 3. Yoram Dinstein, Non-International Armed Conflicts in International Law (Cambridge University Press 2014$) 8$.

62 Adam Roberts, 'The law of war and environmental damage' in Jay Austin and Carl Bruch (eds), The Environmental Consequences of War:Legal Economic and Scientific Perspectives (Cambridge University Press 2010) 76.

63 It must be noted that Common Article 3 will no longer be relevant if the conflict moves outside the border of the High Contracting Party in which it originated.

64 Jeanique Pretorious, 'Enhancing Environmental Protection in Non-International Armed Conflict: The Way Forward' (2018) 78 ZaoRV 903, 905.

65 Roberts (n 62) 76.

66 Pretorious (n 64) 905, 906.

67 Pretorious (n 64) 906. 


\section{Protection of the Environment through the Lens of Syria: Scrutinizing the Loopholes in the Prevailing Legislative Framework 57}

being successful are very weak. ${ }^{68}$ In conclusion, Common Article 3 does not provide a substantive basis for protecting the environment in a non-international armed conflict.

APII is applicable to NIAC and was created to supplement Common Article 3. Moreover, it is applicable to both States and organized armed groups ${ }^{69}$ In APII, there is no directly relevant provision which explicitly protects the environment. However, Articles 14 and 15 may indirectly offer the environment protection in times of a NIAC. ${ }^{70}$ Article 14 of Additional Protocol II reads as follows:

Starvation of civilians as a method of combat is prohibited. It is therefore prohibited to attack, destroy, remove or render useless, for that purpose, objects indispensable to the survival of the civilian population, such as foodstuffs, agricultural areas for the production of foodstuffs, crops, livestock, drinking water installations and supplies and irrigation works. ${ }^{71}$

Article 14 has both positive and negative qualities. It has positively achieved the status of customary international law and cannot be derogated from even in cases of military necessity. ${ }^{72}$ With these constructive elements in mind, it is also important to note a shortcoming in the case of environmental protection. ${ }^{73}$ Strictly speaking, Article 14 offers indirect protection if an attack would lead to the starvation of civilians but does not account for other consequences of the attack, such as the starvation of members of armed groups or the death of civilians. ${ }^{74}$

Article 15 of Additional Protocol II does not regulate water systems per se, but targets:

Works or installations containing dangerous forces, namely dams, dykes and nuclear electrical generating stations, shall not be made the object of attack, even where these objects are military objectives, if such attack may cause the release of dangerous forces and consequent severe losses among the civilian population. ${ }^{75}$

The scope of application of this Article is narrow and limited. ${ }^{76}$ It protects only in the event of attacks which are specifically enumerated therein and excludes the possibility of protection against other type of dangerous installations such as oil fields. ${ }^{77}$ Hence, although APII does contain these two Articles, it does not provide any specific limitations with regard to methods and means of warfare affecting the environment.

\section{What is Non-International Armed Conflict?}

There are generally two types of armed conflict: international armed conflict and noninternational armed conflict. The International Criminal Tribunal for the former Yugoslavia

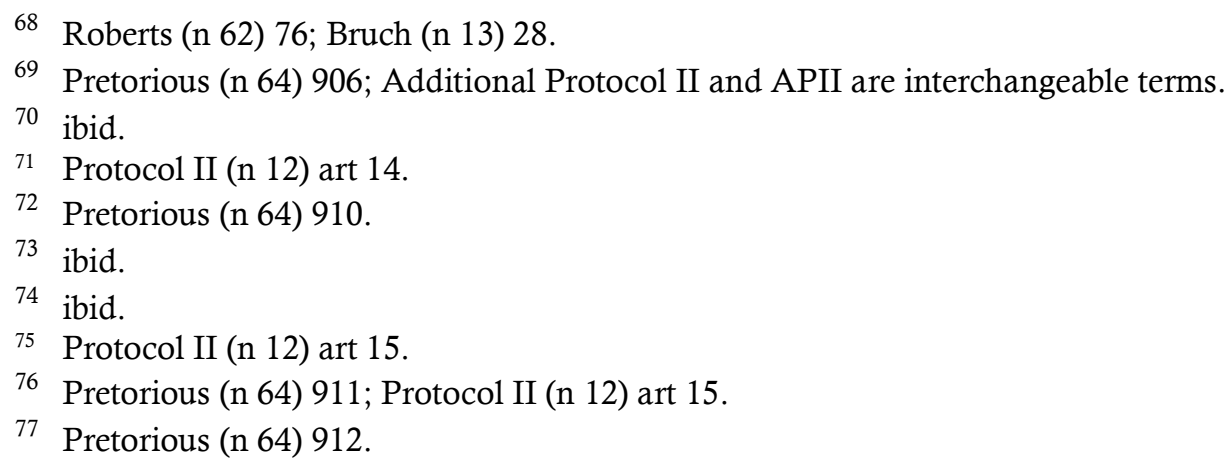


(ICTY) narrowed down the definition of armed conflict to 'a resort to armed force between states or protracted armed violence between governmental authorities and organized armed groups or between such groups within a state'. ${ }^{78}$

The ICTY also differentiated between the two types of conflict by confirming that an international armed conflict can be defined as a conflict including one or more States that resort to armed force against each other or another State ${ }^{79}$ and that a non-international armed conflict happens internally within a State and involves one or more non-State armed groups. ${ }^{80}$

Primarily, according to the travaux préparatoires of the Geneva Conventions, 'armed conflict not of an international character' was understood to be equivalent to a civil war. ${ }^{81}$ Despite this, there is a lack of a uniform legal definition of what precisely is encompassed in the term 'non-international armed conflict'. ${ }^{82}$ However, it is widely agreed that, as outlined in Common Article 3, a non-international armed conflict arises when it takes place within the territory of one of the High Contracting Parties and is between the State and non-State armed groups. Furthermore, Dinstein enumerates five preconditions that must be fulfilled in order for an attack to be classified as a NIAC. ${ }^{83}$ Firstly, he deconstructs the beginning of Common Article 3 which contains the first two conditions: '....armed conflict not of an international character' ${ }^{84}$ Hence, a conflict must firstly be an armed conflict, and secondly must not be of an international character. Moreover, he refers to the ICTY, which commented 'whenever there is ... protracted armed violence between governmental authorities and organized armed groups or between such groups within a State'. ${ }^{85}$

From this, the remaining three requirements can be deduced. Firstly, a certain degree of organization of the non-State party to the armed conflict must exist. The second requirement is 'protracted violence', and thirdly, a certain intensity of fighting. These criteria will be applied to assess the state of the Syrian internal conflict.

Although organizations such as Human Rights Watch and the ICRC confirmed that the conflict in Syria is of an internal nature, it shall be checked against the above criteria. The conflict must be armed and not of an international character: in 2012, a report by the United Nations Independent Commission of Inquiry proved that the conflict is armed by stating that bombings took place and shelling 'with heavy weapons, leading to massive casualties and the destruction of homes and infrastructure' was employed. ${ }^{86}$ There are multiple organized armed groups in Syria, however ISIS and FSA sustain the 'organizational degree of the non-State party' requirement, making it a conflict not of an international character ${ }^{87}$ The last two requirements are 'protracted violence' and intensity of fighting. Regarding 'protracted

78 Prosecutor $v$ Tadic (Judgment in Sentencing Appeals) IT-94-1-A (26 January 2000); Gal (n 7) 30.

79 Note, it is also mentioned that no formal declaration of war or recognition of the situation is required - see ICRC, 'International armed conflict' $(I C R C, 2020)$ <casebook.icrc.org/glossary/international-armedconflict> accessed 9 July 2020.

80 ICRC, 'Non-international armed conflict' (ICRC, 2020) <casebook.icrc.org/glossary/non-internationalarmed-conflict> accessed 9 July 2020; see, inter alia, Geneva Convention (n 12) common art 3.

81 Pejic (n 8) 12.

82 Pejic (n 8) 3.

83 Dinstein (n 61) 20.

84 ibid.

85 ibid.

86 RULAC, 'Non-international armed conflicts in Syria' (RULAC, 22 January 2020) $<$ rulac.org/browse/conflicts/non-international-armed-conflicts-in-syria\#collapse3accord> accessed 9 July 2020.

87 See footnote 23 for analysis. 


\section{Protection of the Environment through the Lens of Syria: Scrutinizing the Loopholes in the Prevailing Legislative Framework 59}

violence', Dinstein further explains that there is no ideal time frame that determines this. However, he points out that the conflict should not suddenly exist but rather start off as 'isolated and sporadic' internal disturbances which eventually turn into a non-international armed conflict. The ongoing internal battle in Syria has been taking place for over eight years, and has included extreme tactics such as 'attacking government-held areas, restricting civilians' ability to flee hostilities, kidnapping, assassinations, car bombings and more' ${ }^{88}$ Therefore, the criteria of 'protracted violence' and intensity of fighting can be fulfilled. The existence of NIAC in Syria is thereby confirmed.

\section{E. Does Customary International Law Supplement International Humanitarian Law?}

Customary international law is a supplementary source of law, affirmed in Article 38 of the Statute of the International Court of Justice. To qualify as an international custom, two requirements must be fulfilled: evidence of general practice and opinio juris. ${ }^{89}$ An interesting argument shared among scholars, including Professor Meron, is that, since it is challenging to classify a conflict as international or non-international, civil wars should enjoy the broader protective rules that are suitable for international armed conflicts. ${ }^{90}$ Thus, Professor Meron explores customary law as a possible strategy for affording the environment more protection in non-international armed conflicts, more specifically within the Martens Clause. ${ }^{91}$ The Martens Clause states that:

Until a more complete code of the laws of war is issued, the High Contracting Parties think it right to declare that in cases not included in the Regulations adopted by them, populations and belligerents remain under the protection and empire of the principles of international law, as they result from the usages established between civilized nations, from the laws of humanity and the requirements of the public conscience. ${ }^{92}$

88 Dinstein (n 61) 35, 36 - Dinstein enumerates the following indications for the criteria of intensity of fighting: 'the numbers of casualties; the diffusion of violence over territory; the deployment of military units against the insurgents; the types of weapons used, the siege of towns, and the closure of roads'; See Human Rights Watch, 'Syria Events of 2018' (Human Rights Watch, 2019) <hrw.org/world-report/2019/countrychapters/syria> accessed 9 July 2020.

89 Statute of the International Court of Justice (adopted 26 June 1945, entered into force 24 October 1945) 33 UNTS 993 (ICJ Statute), art 38; opinio juris mean 'an opinion of law or necessity', ie a practice has to be accepted as law - see Cornell Law School, 'Opinio juris (international law)' (Cornell Law School Legal Information Institute) <law.cornell.edu/wex/opinio_juris_\%28international_law\%29> accessed 9 July 2020.

90 Theodor Meron, 'Comment: Protection of the Environment During Non-international Armed Conflicts' (1996) 69 International Law Studies 354, 355; note, this in turn would offer the environment more protection since the type of conflict would be irrelevant if the law is applied equally.

91 Meron (n 91) 355; the Martens Clause originates from the Preamble to the 1899 Hague Convention (II) with Respect to the Laws and Customs of War on Land. It functions to offer protection in cases where it is not offered in the original, specific rule and as a reminder that customary international law applies after a treaty is adopted. Note, the Martens Clause is mentioned in Chapter VI Protection of the environment in relation to armed conflicts' during the sixty-seventh session when the International Law Commission provisionally drafted Principle 12 - it states: 'In cases not covered by international agreements, the environment remains under the protection and authority of the principles of international law derived from established custom, from the principles of humanity and from the dictates of public conscience.' - see ILC (n 4); see also Rupert Ticehurst, 'The Martens Clause and the Laws of Armed Conflict' (1997) 37 International Review of the Red Cross.

92 Ticehurst (n 91) 125. 
This clause is mentioned in various different treaties, however it is worded slightly differently in each one. ${ }^{93}$ Further discussion about the wording of this Clause and professional opinions thereon is necessary in order to establish whether the Martens Clause could assist with the protection of the environment in non-international armed conflicts.

In essence, the Martens Clause is relevant to the law of armed conflict as it is a basic provision of international humanitarian law. ${ }^{94}$ However, the issue that arises among experts is how the Clause should be interpreted, as there is no generally accepted interpretation. ${ }^{95}$ Judge Shahabuddeen in his Dissenting Opinion on the Threat or Use of Nuclear Weapons dictates that the Court confirms the Martens Clause is a customary rule. ${ }^{96}$ Furthermore, he claims that 'the Martens Clause is not just a reminder of the existence of different norms in international law which are not given in a specific treaty, but that the Clause has a normative status in its own right and works separately from other norms. ${ }^{, 97}$ Therefore, the Clause could offer support and serve as a supplementary source of customary international law alongside the provisions that will be discussed next.

It has already been mentioned that Articles 35(3) and 55(1) API apply to international armed conflict. However, with the development of customary international law, it is pertinent to discuss whether these Articles can be extended to non-international armed conflicts. This has been discussed by the ICRC in a study on customary international law wherein they argued that Articles 35(3) and 55(1) can be applied in a NIAC. ${ }^{98}$ It was discussed under the first part of Rule 45, which reads: 'The use of methods or means of warfare that are intended, or may be expected, to cause widespread, long-term and severe damage to the natural environment is prohibited. ${ }^{99}$

Regarding Articles 35(3) and 55(1) API, many considerations were made. It was explained that when API was first ratified, there was concern expressed by France, the United Kingdom and later by the United States. ${ }^{100}$ However, since ratification, State practice has consistently reflected that this prohibition has become customary. ${ }^{101}$ In the Threat or Use of Nuclear Weapons case, various States submitted that they believe both Articles 35(3) and 55(1) to be customary. ${ }^{102}$ Interestingly, the ICJ considered that, on the contrary, it is "not to be

93 See Additional Protocol II (n 12) preamble: 'Recalling that, in cases not covered by the law in force, the human person remains under the protection of the principles of humanity and the dictates of the public conscience'.

94 Bruch (n 13) 46.

95 Ticehurst (n 91) 125, 126.

96 Legality of the Threat or Use of Nuclear Weapons (Advisory Opinion) (Dissenting Opinion Judge Shahabuddeen) [1996] ICJ Rep 226.

97 ibid.

98 Britta Sjöstedt, "The Role of Multilateral Environmental Agreements in Armed Conflict: "Green-Keeping" in Virunga Park. Applying the UNESCO World Heritage Convention in the Armed Conflict of the Democratic Republic of the Congo' (2013) 82 Nordic Journal of International Law 129, 135; see also JeanMarie Henckaerts and Louise Doswald-Beck, Customary International Humanitarian Law Volume 1: Rules (Cambridge University Press 2005) 143-158.

99 Henckaerts and Doswald-Beck (n 98) 151.

${ }^{100}$ Henckaerts and Doswald-Beck (n 98) 153 - both the US and UK are doubtful of whether or not the phrasing 'may be expected to cause' is of a customary nature. The US voiced their opposition to this Rule being customary in response to an ICRC memorandum on the applicability of international humanitarian law in the Gulf region in 1991.

${ }^{101}$ Henckaerts and Doswald-Beck (n 98) 152 - this is further evident because the prohibition is included in multiple military manuals and is an offense under the legislation of a number of States.

102 ibid. 


\section{Protection of the Environment through the Lens of Syria: Scrutinizing the Loopholes in the Prevailing Legislative Framework 61}

customary as it only referred to the applicability of this provision to "States having subscribed to these provisions". ${ }^{103}$ Despite this differing view from the Court, it is not substantial enough to prevent the emergence of this customary rule. ${ }^{104}$ Furthermore, practice in terms of the methods of warfare and the use of conventional weapons 'shows a widespread, representative and virtually uniform acceptance of the customary law nature of the rule found in Articles 35(3) and 55(1) of API'. ${ }^{105}$ In conclusion, the ICRC stated that this Rule has developed into customary international law with France, the United Kingdom, and the United States as persistent objectors. ${ }^{106}$ The utility of these Articles will be discussed in the last subsection of this thesis.

\section{Why Define the '(Natural) Environment'?}

In international humanitarian law, it is often heavily disputed what the term 'natural environment' encompasses, since there is no clear-cut, universal definition thereof. ${ }^{107}$ Hence, these different viewpoints as to what the 'natural environment' is and what differentiates it from simply the 'environment' pose an ongoing challenge. Expert Mollard-Bannelier offers some insight and argues that 'the definition of environment has not yet been unified because of the fact that an updated description would constantly be necessary as scientific knowledge would continue to alter our understanding. ${ }^{108}$

This raises a critical issue with many open-ended questions that must be confronted: what precisely is the definition of 'natural environment' in the international legal framework? It is pivotal to assess the meaning of 'natural environment' because it could vary between sources. Additionally, does the term 'natural environment' encompass more than 'environment' or vice versa? More specifically, can we precisely distinguish between 'natural environment' and 'environment'? Since the appropriate wording is a disputable matter, guidance shall be taken from the international humanitarian law perspective, which qualifies the environment as being 'natural'. ${ }^{109}$ Hence the meaning of 'natural environment' will firstly be assessed, followed by an assessment of 'environment'. After the presentation of both

${ }^{103}$ Legality of the Threat or Use of Nuclear Weapons (Advisory Opinion) [1996] ICJ Rep 226; Henckaerts and Doswald-Beck (n 98) 153, 154.

104 Henckaerts and Doswald-Beck (n 98) 154

105 ibid.

106 Erik Koppe, The Use of Nuclear Weapons and the Protection of the Environment during International Armed Conflict (Hart Publishing 2008) 244; C Greenwood, Customary Law Status of the 1977 Geneva Protocols in Delissen and Tanja (eds), Humanitarian Law of Armed Conflict; Challenges Ahead; Essays in Honour of Frits Kalshoven (Martinus Nijhoff 1991) 105.

107 Weir (n 14); see, inter alia, Alexandre Timoshenko, 'Conclusions by the Working Group of Experts on Liability and Compensation for Environmental Damage Arising from Military Activities, in Liability and Compensation for Environmental Damage' (Compilation of Documents, United Nations Environmental Programme, 1998) quoted in Cymie Payne and Peter Sand (eds), Gulf War Reparations and the UN Compensation Commission: Environmental Liability (Oxford University Press 2011); note, in international humanitarian law, 'natural environment' is accepted as opposed to 'environment'.

${ }^{108}$ Cymie Payne, 'Defining the Environment' in Carsten Stahn, Jens Iverson, Jennifer S Easterday (eds), Environmental Protection and Transitions from Conflict to Peace: Clarifying Norms, Principles, and Practices (Oxford Scholarship Online 2017) 41.

109 Weir (n 14); hence, since this is the common view in international humanitarian law, the natural environment will firstly be addressed, then the notion of 'environment' will be considered. 
meanings, a grey area filled with inconsistencies regarding the definition will be visible and further discussed.

\section{A. Diverse Definitions of 'Natural Environment': Investigating the Inconsistencies}

There are disparate meanings circulating amongst academics as to what the 'natural environment' comprises, but they do not differ immensely, and an analogy will be visible. This is precisely observed by researcher Peterson who professes that: 'generally, definitions of "natural environment" mention "a whole complex of non-living and living factors which act upon an organism or ecological community, which eventually determine its form and survival"'. 110

This thesis focuses on non-international armed conflict and the specifically applicable sources, Common Article 3 and Additional Protocol II. However, in neither of these legal sources is there a definition of 'natural environment'. ${ }^{111}$ The phrase 'natural environment' first debuted in an IHL instrument in 1977, in Additional Protocol I to the Geneva Conventions. ${ }^{112}$ Although Articles 35(3) and 55(1) API refer to the natural environment, there is no definition or further explanation given of what is exactly denoted by 'natural environment'. ${ }^{113}$ This issue is discussed in the 1977 ICRC Commentary on the Additional Protocols to the Geneva Conventions wherein it is stated that 'natural environment' should be interpreted as widely as possible. ${ }^{114}$ Commentary 2126 states that:

The concept of the natural environment should be understood in the widest sense to cover the biological environment in which a population is living. (...) It does not consist merely of the objects indispensable to survival (...) but also includes forests and other vegetation (...), as well as fauna, flora and other biological or climatic elements. ${ }^{115}$

110 Ines Peterson, 'The Natural Environment in Times of Armed Conflict: A Concern for International War Crimes Law?' (2009) 22 Leiden Journal of International Law 325, 328; note, 'non-living' may also be referred to as 'abiotic' and living as 'biotic'. Hence, these terms can be used interchangeably. The author also makes note of the fact that international environmental treaties affirm elements such as 'flora and fauna', 'air', 'soil', 'water', 'vegetation', 'habitat', 'forests', 'marine living resources', 'ecosystems', 'organism', 'climate', and 'agriculture' as belonging to the 'environment'. This is pointed out because it provides clarity and room for comparison when observing definitions in different areas of law. However, the rest of the discussion will circulate around international humanitarian law as opposed to international environmental law.

111 Yoram Dinstein, 'Protection of the Environment in International Armed Conflict' (2001) 5(1) Max Planck Yearbook of United Nations Law Online 523, 540 - as Dinstein further pointed out, reference to the ENMOD Convention is possible. However, this Convention will be disregarded because it protects the environment from environmental modification techniques and from being used as a weapon; see Antoine Bouvier, 'Protection of the natural environment in time of armed conflict' (1991) 31 International Review of the Red Cross 567, 576; the lack of a provision in APII that is analogous to Articles 35(3) and 55(1) API was raised and a proposition was made at the Diplomatic Conference on the Reaffirmation and Development of International Humanitarian Law applicable in Armed Conflicts (CDDH). Unfortunately, this was rejected.

112 Hans-Peter Gasser, 'For Better Protection of the Natural Environment in Armed Conflict: A Proposal for Action' (1995) 89 The American Journal of International Law 637, 638.

113 ibid.

114 ibid.

115 Yves Sandoz, Christophe Swinarski and Bruno Zimmermann (eds), Commentary on the Additional Protocols: of 8 June 1977 to the Geneva Conventions of 12 August 1949 (Martinus Nijhoff Publishers 1987) comment 2126; see Weir (n 14). 


\section{Protection of the Environment through the Lens of Syria: Scrutinizing the Loopholes in the Prevailing Legislative Framework 63}

This commentary is important because it reveals that this was a concern of the ICRC at the time of writing. Moreover, this commentary provides a broad definition of what is encompassed by 'natural environment'. It could positively be argued that this wide margin of appreciation better protects the environment by offering a broad range of what can be safeguarded, as opposed to other definitions.

A few decades later, it can be observed that this is still a concern within the international legal sphere as the Parliamentary Assembly of the Council of Europe in their 2011 Report on 'Armed Conflicts and the Environment' argues that 'the natural environment is neither defined in Article 35(3) nor in Article 55(1) of Protocol I to the Geneva Conventions yet it makes reference to the natural environment.' 116

Although international humanitarian law frequently refers to the 'natural environment' as opposed to the 'environment', the ongoing challenge, as noted by both the ICRC and the Parliamentary Assembly, is that 'natural environment' is not properly and uniformly defined. ${ }^{117}$

Fascinating observations are made by the International Law Commission in various reports on 'Protection of the Environment in Relation to Armed Conflicts' and the meaning of 'natural environment'. ${ }^{118}$ In Report $A / 70 / 10$ the 'environment' is defined solely as 'environment', however Principles 1 and 4 refer to 'natural environment'. ${ }^{119}$ This was raised as a concern by members who claimed the lack of uniformity of terms created confusion and inconsistency. ${ }^{120}$ The Special Rapporteur of the ILC commented on this differentiation by stating that 'the rationale behind the usage of these two variations was due to the scope which was wide when referred to simply "environment"'. ${ }^{121}$

The provisions concerning the law of armed conflict enjoyed a narrower approach, hence the term 'natural environment' was used. It was further explained that the use of 'natural environment was to avoid broadening the scope of the law of armed conflict'. ${ }^{122}$ This Report brings to light two important issues: on the one hand, interchangeably using 'environment' and 'natural environment' can cause confusion, as was addressed by States. On the other hand, it is clear that 'natural environment' is used when discussing the scope of the law of armed conflict. ${ }^{123}$ Two conclusions can be observed. Firstly, from the Report, it can be devised that there is a grey area that causes inconsistencies within the international legal framework when referring to the natural environment versus the environment, if these terms are not adequately explained and differentiated. Secondly, the ICRC, PACE and ILC all acknowledge the fact that the 'natural environment' is not yet properly defined within international humanitarian law.

\footnotetext{
116 Huseynov (n 2); Protocol I (n 12).

117 Weir (n 14).

118 The ILC was created by the General Assembly in 1947. Their objective is to issue recommendations with the intention of encouraging the progressive expansion and growth of international law - see UN, 'International Law Commission' (United Nations, 2020) <legal.un.org/ilc/> accessed 9 July 2020.

119 ILC (n 4) - the definition of 'environment' provided in the Report is the following: it 'includes natural resources, both abiotic and biotic, such as air, water, soil, fauna and flora and the interaction between the same factors, and the characteristics of the landscape.'.

${ }^{120}$ ILC (n 4) 108 - see the general comment made under point 145.

121 ILC (n 4).

122 ILC (n 4) 114 - see concluding remark 166 by the Special Rapporteur.

${ }^{123}$ ILC (n 4).
} 


\section{B. 'Natural Environment' versus 'Environment'}

In order to understand the dynamic between the 'natural environment' and 'environment' in IHL, it is important to examine a few references to the term 'environment'. A well-known definition is provided by the International Court of Justice, which offers an ardent, nonbinding explanation of the term in its Legality of the Threat or Use of Nuclear Weapons Advisory Opinion: 'the environment is not an abstraction but represents the living space, the quality of life and the very health of human beings, including generations unborn'. ${ }^{124}$

It should be noted that the Court provides this definition but does not further elaborate on terms such as 'living space', and this in turn can be interpreted in a variety of ways with potentially harmful effects on the environment.

The 1972 Stockholm Declaration was created for the preservation and enhancement of the environment, and declares in Principle 1 the 'fundamental right to ... an environment of a quality that permits a life of dignity and well-being'. ${ }^{125}$ Here, it is visible that environmental problems are an underlying, essential part of the fundamental rights of human beings because there is a correlation between human safety and a habitable environment. ${ }^{126}$ This will be briefly examined in light of the conflict occurring in Syria. ${ }^{127}$

A definition was given in the 70th session of the International Law Commission wherein it was stated that "environment" includes natural resources, both abiotic and biotic, such as air, water, soil, fauna and flora and the interaction between the same factors, and the characteristics of the landscape.' ${ }^{28}$

A pattern is visible regarding each definition. Crucial terms such as 'living space', 'characteristics of the landscape', and 'a life of dignity and well-being' are not adequately described. This presents an opportunity for international and non-international actors who committed a wrongdoing and damaged the environment to interpret it in such a way that benefits them and rids them of any responsibility for the harm caused to the environment. ${ }^{129}$ As briefly stated above, it is to some extent understandable that to create a universally applicable definition of the natural environment is problematic due to the constant

124 Henckaerts and Doswald-Beck (n 98) 152.

125 See United Nations, 'Report of the United Nations Conference on the Human Environment' (1 January 1973) UN Doc A/CONF.48/14/Rev.1 - note only the relevant aspect of the Principle is stated; the Principle in full reads: 'Man has the fundamental right to freedom, equality and adequate conditions of life, in an environment of a quality that permits a life of dignity and well-being, and he bears a solemn responsibility to protect and improve the environment for present and future generations. In this respect, policies promoting or perpetuating apartheid, racial segregation, discrimination, colonial and other forms of oppression and foreign domination stand condemned and must be eliminated.'; Furthermore, this is an interesting example of how the environment is not constricted to what a lay-person may perceive it to be but extends to include human rights - see Steven Freeland, 'Human Rights, the Environment and Conflict: Addressing Crimes against the Environment' (2005) 2 SUR International Journal on Human Rights 112.

126 Freeland (n 125) 113.

127 Zwijnenburg and te Pas (n 6) 11, 14, 18, 19 - note, there will be reference to the Stockholm Declaration when discussing the lack of an efficient water system due to damage caused by the internal conflict resulting in harm to the well-being of humans. It will be further argued that this is damaging the environment.

128 ILC (n 4).

129 Karine Bannelier-Christakis, 'International Law Commission and Protection of the Environment in Times of Armed Conflict: A Possibility for Adjudication?' (2013) 20 Journal of International Cooperation Studies 129, 131, 140 - the author specifically refers to ILC Member Marie Jacobsson, who has actively been recognizing the necessity for the ILC to continue developing legislation surrounding the recognition and protection of the environment, because although there has been notable progress it still remains vague; see also ILC, 'Report of the International Law Commission on the work of its sixty-third session' (2011) A/66/10. 


\section{Protection of the Environment through the Lens of Syria: Scrutinizing the Loopholes in the Prevailing Legislative Framework 65}

development of scientific knowledge. ${ }^{130}$ Again, this presents a certain grey area, since it is challenging to protect the 'natural environment' if officially there is no singular definition thereof. ${ }^{131}$

The conclusion that can be drawn from this analysis is that no certain definition of what encompasses environment, and more importantly 'natural environment', exists. What does exist is a variety of definitions that offer more or less the same amount of protection for the environment, and consequently none of them bring the environment sufficient justice. Thus, further references made in this thesis will refer to 'natural environment' and be understood in the broadest scope possible. This will allow for a wider margin of applicability and a broader analysis of what the natural environment entails, and what in turn can be protected.

\section{The Assessment: Linking the Water Crisis to Environmental Damage}

In this last Section, an assessment and analysis will take place. Consistent reference has been made in this thesis to damage the natural environment in Syria has sustained. Hence, it is critical to firstly confirm whether the damage to the water system can be connected to environmental damage. If so, it will be then questioned whether international humanitarian law can offer the natural environment any protection amidst the Syrian conflict.

Perhaps, at first glance, the discussed damage to the water systems does not appear to affect the natural environment physically. However, it can be presumed that this damage caused contamination which could have seeped into the soil as the result of a leak or the blow of an attack and caused soil pollution. ${ }^{132}$ Furthermore, it can be extended to say that there is water pollution resulting in damage that is perhaps not accounted for due to a lack of efficient studies. Alternatively, the shortage of water can result in agricultural damage and an inability to properly care for the soil and the natural environment. This can be reaffirmed by the estimate that, due to the conflict, around 300,000 farming families left for other cities. This in turn left large areas of agricultural land unattended. ${ }^{133}$

With the analysis of what the 'natural environment' entails, it has been established that in order to best carry out a further analysis regarding the case study of Syria, a wide margin of appreciation would be presumed. Applying a wide margin of appreciation to the damage being done in Syria with regard to the water system is appropriate, since, as mentioned, the blockage of suitable water has diminished the standards of living in Syria. Moreover, the Commentary to the Additional Protocols discussed above stated that "natural environment" should be elucidated as widely as possible. ${ }^{134}$ Hence, it would not be incorrect to say that the water crisis

130 Payne (n 108).

131 The Office of the Prosecutor, 'Policy paper on case selection and prioritisation' (International Criminal Court, 15 September 2016) <icc-cpi.int/itemsDocuments/20160915_OTP-Policy_Case-Selection_Eng.pdf> accessed 9 July 2020 - this report includes distinct points referencing the Court s capability to prosecute individuals for causing harm to the environment. Specifically, points 7, 40 and 41 all mention the investigation of destruction to the environment. Although references are made to the 'destruction of the environment', nowhere within the Policy Paper is a definition of the environment available. It must be recognized that this is a tremendously important step forward for the protection of the environment and is evidence that progress is being pursued. Nonetheless, the underlying issue is still present: how can we protect the 'natural environment' or the 'environment' if the meaning of the term is unclear?

132 Zwijnenburg and te Pas (n 6) 19, 29.

133 ibid.

${ }^{134}$ Gasser (n 112). 
in Syria is resulting in environmental damage because it is countermanding a 'life of dignity and well-being'. ${ }^{135}$ Due to this wide perspective, the damage to the water system by military attacks will qualify as damage to the natural environment. Hence, this must be assessed in light of international humanitarian law to ascertain whether or not a provision thereof can be used to protect the environment from further damage.

\section{A. Can the Law of Non-International Armed Conflict Protect the Syrian Environment?}

It has been reiterated that the conflict in Syria is of a non-international and armed nature, therefore the application of certain provisions proves to be problematic. The jus in bello mentioning environmental protection is found in Additional Protocols I and II to the Geneva Conventions.

Firstly, the provisions pertaining to non-international armed conflicts will be reviewed and it will be discussed whether they are applicable to the damage to the water systems in Syria. Common Article 3 is a general provision applicable to non-international armed conflict, but it does not explicitly relate to or mention the natural environment or water systems. Arguing purely on the basis of Common Article 3 would therefore be unsuccessful in attempting to halt the damage occurring in Syria. Some scholars, such as Pretorious, attempt to broaden the scope of this Article to include the environment. ${ }^{136}$ However, in practice, this is neither feasible nor successful. Common Article 3 could be used as a supplementary article; however, it would not be victorious on its own.

Additional Protocol II as a whole is applicable to non-international armed conflict. It does not specifically mention the 'natural environment', but it does contain Articles 14 and 15 relating to water systems. These Articles are a positive result of the development of legislation to include more environmentally conscious terms. However, they are not perfect. Article 14 could provide indirect environmental protection in the case of Syria, specifically if an attack destroyed drinking water installations and supplies. ${ }^{137}$ However, Article 14 states that attacks are only prohibited if they would result in the starvation of civilians. Therefore, the attacks on the water system would either have to render a situation where, due to loss of water, civilians lose copious amounts of crops resulting in a famine, or a total loss of water throughout the whole country. The likelihood of this occurring is small since these scenarios are very specific, and other outcomes such as death, or the starvation of armed opposition groups, are not mentioned. On the other hand, Article 15 refers to the prohibition of attacks on works or installations containing dangerous forces. Article 15 would be unsuccessful in protecting the natural environment from damage to water systems because, even if the water system was linked to something containing a dangerous force, it is not explicitly covered by this Article. Hence, it would not be plausible to argue effectively in this respect.

An interesting observation was made by Desgagné, who argues that 'Thus, the provisions of the Hague or the Geneva Conventions, through the protection of civilian property and objects, offer indirect protection of the environment. (...) ${ }^{\prime 138}$ This argument is true; however, the bigger picture must be considered. Namely, in the law of non-international armed conflict there is no provision which would truly protect the natural environment.

\footnotetext{
135 Sandoz, Swinarski, and Zimmermann (n 115).

${ }^{136}$ Pretorious (n 64) 905, 906.

137 Pretorious (n 64) 910.

138 Desgagné (n 16) 109.
} 


\section{Protection of the Environment through the Lens of Syria: Scrutinizing the Loopholes in the Prevailing Legislative Framework 67}

Perhaps the even bigger question is: what is the natural environment? As discussed above, this is a grey area as no universal definition exists. Does the lack of a specific definition in IHL result in a lack of protection for the natural environment? Or, is the law on NIAC simply not as developed as the law on IAC? The answer is probably a mixture of both the lack of a specific definition and the lack of precise, specific provisions which offer exclusive protection to the natural environment in times of non-international armed conflict. ${ }^{139}$

\section{B. The Law of Armed Conflict: A Customary International Law Perspective}

The Articles applicable to international armed conflict will be assessed as customary international law. Articles 35(3) and 55(1) API regulate conduct affecting the natural environment and there are various viewpoints as to whether or not these should qualify as custom. It must be brought to light that practice, in terms of methods of warfare and the use of conventional weapons, 'shows a widespread, representative and virtually uniform acceptance of the customary law nature of the rule found in Articles 35(3) and 55(1) of API'. ${ }^{140}$

Moreover, the ICRC concluded that this Rule has developed into customary international law with France, the United Kingdom, and the United States as persistent objectors. ${ }^{141}$ An interesting point worth noting is that the view that Articles 35(3) and 55(1) are not customary international law was once widely supported in literature. Greenwood argued in 1991 that 'There is little or no subsequent practice which might have had the effect of incorporating the principle stated therein into customary law' ${ }^{142}$ Despite this viewpoint, it is customary to qualify these two Articles as also applying to non-international armed conflicts.

Therefore, the question is: can they sufficiently prevent further environmental damage in Syria?

The Articles both present a triple requirement that, during an armed conflict, there is an absolute prohibition on causing damage that would be 'widespread, long-term, and severe Articles. these regarding literature in mentioned consistently is point important $\mathrm{An}^{143}$.' For example, Bothe, Bruch, Diamond, and Jensen argue 'that Articles 35(3) and 55(1) are "excessively restrictive and unclear" because they contain the conjunction "and", meaning that the damage must fulfill all three requirements, two of which are not fully explained.'144

Hence, it would be difficult to argue under these Articles, as both not only contain the triple requirement of the damage being long-term, widespread, and severe but the terms 'widespread' and 'severe' are not properly defined. 'Long-term' was explained by the Protocol as 'a period of at least ten years'. ${ }^{145}$ Therefore, even if the other two requirements were valid, the Syrian conflict erupted in 2011 and was classified as a NIAC in 2012. ${ }^{146}$ Therefore, as of 2020 it would not have surpassed the ten-year minimum.

\footnotetext{
139 ibid.

140 Henckaerts and Doswald-Beck (n 98) 154.

141 Koppe (n 106) 244.

142 Greenwood (n 106) 105.

143 Protocol I (n 12) arts 35(3), 55(1).

144 Michael Bothe and others, International law protecting the environment during armed conflict: gaps and opportunities' (2010) 92 International Review of the Red Cross 569, 570, 572.

145 Wil Verwey, Protection of the Environment in Times of Armed Conflict: In Search of a New Legal Perspective' (1995) 8 Leiden Journal of International Law 7, 10.

146 Arimatsu and Choudhury (n 19).
} 
In conclusion, if the Syrian conflict continues to escalate and cause damage to the environment, then in the future Articles 35(3) and 55(1) could be applicable. As of now, however, they are not very helpful due to the high threshold that must be met for them to become applicable.

\section{Conclusion}

A number of conclusions can be drawn from the presented research and analyses; however, a few important ones will be iterated. The main aim of this thesis was to present the current legal framework that protects the environment from damage sustained during noninternational armed conflict and to apply it to the specific case study of Syria, with focus on the water systems. From this, the following conclusions can be derived.

The first conclusion is that the current legal framework is not sufficiently expanded and specific to do the environment justice. There have been multiple environmental attacks in Syria and no steps towards the termination of these have been taken due to the lack of applicable legislation. Common Article 3 and APII prove to be hopeful to a certain extent but are definitely not substantial enough to stand on their own. Although customary international law status has been found in Articles 35(3) and 55(1) API, which specifically relate to the natural environment, the required threshold in these Articles is too high and imprecise to apply to the damage caused in Syria. Thus, current international humanitarian law proves to be unsuccessful in protecting the natural environment in Syria.

The second conclusion is that there is a definite grey area when addressing the natural environment in international humanitarian law. With regard to the terms 'natural environment' and 'environment', there is no clear distinction and they are used interchangeably throughout various legal sources, which ultimately stimulates confusion. This presents two issues: firstly, the natural environment is not accurately represented within the legal framework, and secondly, this should urge legislators to reasonably reevaluate the outdated legislation regarding the definition of the natural environment.

The analytical findings were applied to the Syrian non-international armed conflict and the damage which is resulting. The last obvious conclusion is that there is damage occurring to the natural environment. More precisely, the attacks are ruining the water systems which is having diverse effects such as seeping into the soil, causing water pollution, and creating airborne diseases. A subsequent issue that was assessed was the effect the attacks are having on the existence of a suitable environment for the health of human beings. Moreover, the findings repeatedly conclude that damage to the water systems and the water scarcity that is ongoing is not providing a safe environment, thereby risking the health of peoples.

In conclusion, this thesis presents two threats to the environment: the first threat arises from the physical damage that the environment endures as a result of attacks, and the second is the abstract damage that is the consequence of insufficient protection for the environment within the legislative framework. 